Manuscript for Oxford German Studies 2017/2: Special Issue ,German Manuscripts in Oxford“ copy-edited by Henrike Lähnemann and Birgit Mikus, 20 April 2017

\title{
Love in Context:
}

Oxford, Bodleian Library, MS. Laud Misc. 479 and Munich, Bayerische Staatsbibliothek cgm 133

\author{
Ben Morgan \\ University of Oxford
}

\begin{abstract}
English: The article contrasts the versions of Meister Eckhart's Sermon 60 to be found in two manuscripts. The sermon replaces the more usual Dominican emphasis on intellect with a privileging of love as the highest power. The differing responses to this unusual line of argument in the two manuscripts give a concrete sense of the puzzlement provoked by Eckhart's preaching, and of the different strategies by which Eckhart's texts shaped or were themselves shaped by the spiritual milieu in which they were encountered.
\end{abstract}

Abstract German:

Keywords: Meister Eckhart, Embodied Cognition, Intellect, Love, Überlieferungsgeschichte

Meister Eckhart's vernacular sermons, in Dominican fashion, sometimes privilege the intellect over the will: 'Dâ von bin ich aleine sælic, daz got vernünftic ist und ich daz bekenne [I am only blessed because God is intellectual and I know it].' ${ }^{1}$ However, in other sermons, such as Sermon 60 or Sermon 103, Eckhart's preaching takes his readers and listeners beyond intellect to a point where concepts reach their limit: 'Dar umbe enwürket got sîniu götlîchiu werk niht in der bekantnisse, wan si in der sêle mit mâze begriffen ist; mêr: er würket sie als got götlich [God does not perform his works in the understanding, for this is bound in the soul by measure, but He performs them divinely as God]. ${ }^{2}$ These moments caused problems for late medieval readers of his texts, and I want in this brief note to contrast two manuscripts that record traces of such puzzlement. One of the manuscripts is Bodleian MS. Laud Misc 479, which, after the discussions of Freimut Löser and Volker Mertens, needs no further introduction. The other is Bayerische Staatsbibliothek cgm 133, which was recently re-described and re-dated by Karin Schneider to the 1320s, suggesting it

\footnotetext{
${ }^{1}$ Niklaus Largier and Josef Quint, eds, Meister Eckhart Werke, 2 vols., vol. 20-21, Bibliothek Des Mittelalters (Frankfurt a.M.: Deutscher Klassiker Verlag, 1993), I, p. 112; Eckhart, German Sermons \& Treatises, trans. Maurice O'C Walshe, 3 vols. (Shaftesbury: Element Books, 1979), II, p. 153.

${ }^{2}$ Largier and Quint, I, p. 640; Eckhart, II, p. 15. Recent, detailed discussions of Sermon 60 (Ben Morgan) and Sermon 103 (Loris Sturlese) can be found in Georg Steer and Loris Sturlese, eds., Lectura Eckhardi IV: Predigten Meister Eckharts von Fachgelehrten gelesen und gedeutet (Stuttgart: Kohlhammer, 2017), pp. 63-94, pp. 17199.
} 
was potentially compiled during Eckhart's lifetime. ${ }^{3}$ It is a small, unadorned manuscript, which can travel easily, and is also suitable for private study. Alongside an Eckhart sermon, we find, among other things, the radical pseudo-Eckhartian tract 'Sister Catherine'. If the Oxford manuscript of the Paradisus anime intelligentis puts Eckhart's texts amongst examples of preaching redacted for an educated Dominican readership, the Munich manuscript collects Eckhartian texts and an episode from John's Gospel in a portable form, perhaps for lay readers. Both manuscripts contain versions of the text that, in the critical edition of Eckhart's work, is published as Sermon 60.

The part of the sermon that I want particularly to focus on is the moment when Eckhart argues that the human intellect is limited by the way it imposes a conceptual grid on what it knows: the mind compares the objects of experience to its own standards. It thus knows only what fits its own measure (mâze). Having said that God therefore bypasses the understanding, Eckhart tells his listeners what happens next as the soul moves towards union with divinity:

Sô tritet diu oberste kraft hervür - das ist diu minne - und brichet in got und leitet die sêle mit der bekantnisse und mit allen irn kreften in got und vereinet sie mit gote.

[Then the highest power steps forth - which is love - and breaks into God leading the soul with understanding and all her powers into God and unites her with God]. ${ }^{4}$

The equation of love with the highest power is well attested in the transmisison of the sermon. ${ }^{5}$ Neverless, the Oxford manuscript simply excises the idea: 'So tridit di uberste craft her fore und brichit in got [Then the highest power steps forth and breaks into God]' (fol. $66 \mathrm{v}$, fig. 1). The Munich manuscript, by contrast, retains the idea of love (BSB cgm 133, fol. $73 r)$.

\footnotetext{
${ }^{3}$ Karin Schneider, 'Die Eckhart-Handschrift M 1 (Cgm 133)', in Mittelhochdeutsch: Beiträge zur Überlieferung, Sprache und Literatur, ed. Ralf Plate and Martin Schubert (Berlin: de Gruyter, 2011), pp. 165-76.

${ }^{4}$ Largier and Quint, I, p. 640; Eckhart, II, p. 15.

${ }^{5}$ Die Deutschen Werke, ed. Josef Quint and Georg Steer, 5 vols. (Stuttgart: Kohlhammer, 1936-), III, p. 26. See also Freimut Löser, "Einzelpredigt und Gesamtwerk. Autor- und Redaktortext bei Meister Eckhart," Editio 6 (1992), 43-63, here p. 58.
} 


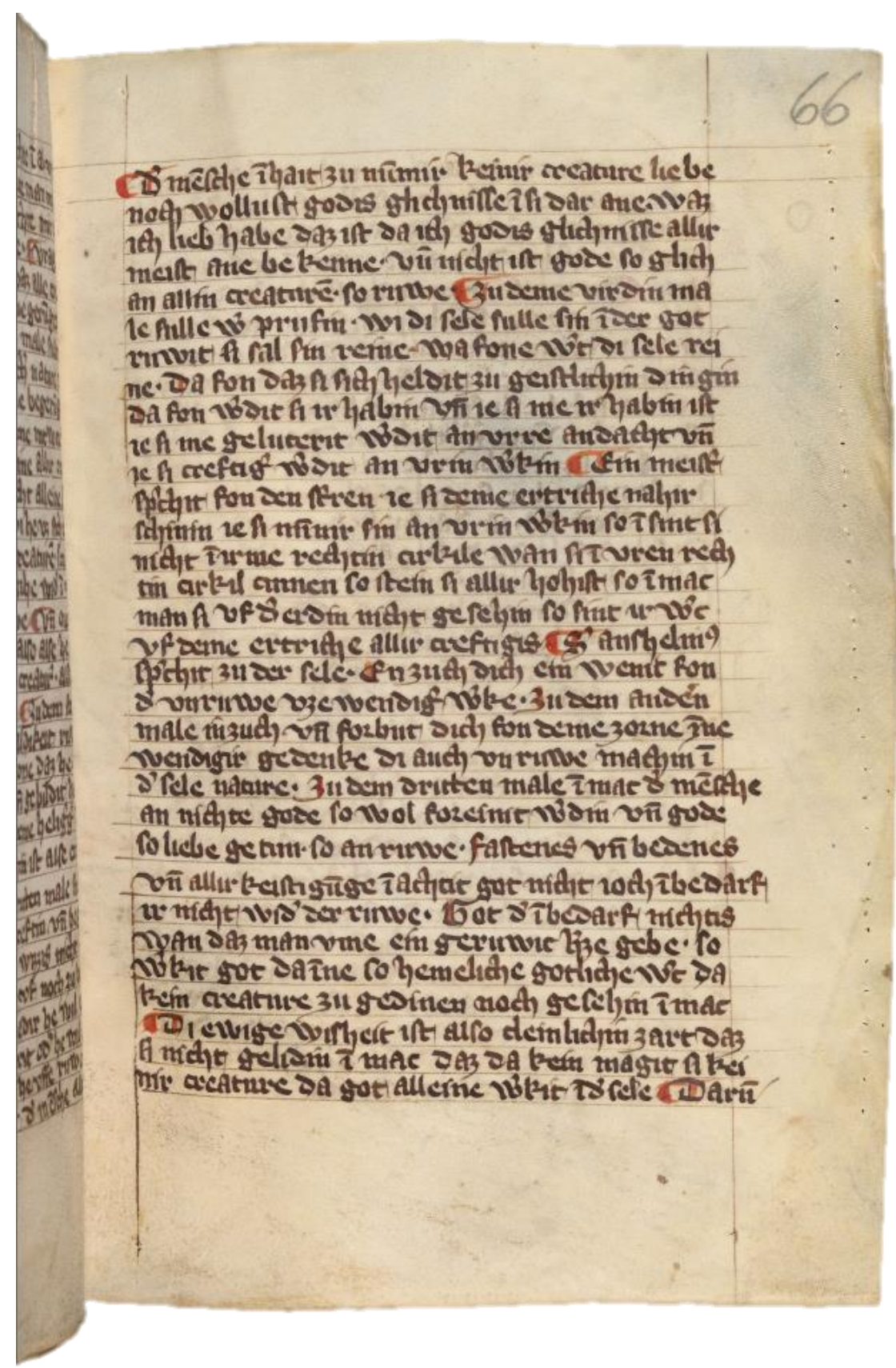

Fig. 1: Bodleian Library, MS. Cod. Laud Misc. 479, fol. 66v.

The Oxford omission fits well with the overall programme of the Paradisus anime intelligentis. ${ }^{6}$ The collection uses Eckhart's text to promote its programme, and the sermons are accordingly cut where they stray into areas that contradict or complicate the redactor's overall message. The Munich manuscript does not exhibit the same editorial control and this different attitude in the underlying projects, and the associated level of education of compiler and projected reader, suggest an explanation for a further discrepancy between the two manuscripts.

\footnotetext{
${ }^{6}$ Burkhard Hasebrink, 'Studies on the Redaction and Use of the Paradisus Anime Intelligente', in Jacqueline Hamesse and Xavier Hermand, eds., De l'homélie au sermon: Histoire de la prédication médiévale (Louvain-laneuve: Publication de l'Institut d'Études Médiévales, 1993), pp. 143-58.
} 
Eckhart's text continues by asserting that the soul, taken by the power of love, breaks into God and is united with God in such a way that He does not so much act in the soul, since that would still suggest a distinction between the soul as vehicle and God as agent, but rather acts divinely simpliciter. To illustrate this melding of the human soul with divinity, Eckhart borrows an image from Aristotelian, that is to say Thomist, biology, which believed that the intellectual soul animated the foetus forty days in to pregnancy for a boy, and ninety days in for a girl.? In Eckhart's text, the Aristotelian idea of a soul inextricably combined with body becomes a metaphor for the way God is inextricably combined with a human soul. Hylomorphism becomes, for the Dominican preacher, a powerful and, for a least one reader, surprising tool for conceptualizing the relation between the mortal and the divine:

Als man prüeven mac bî einem glîchnisse, als die meister schrîbent von natûre: swenne daz kint enpfangen wirt in der muoter lîbe, sô hât ez lidemæze und varwe. Swenne aber diu sêle gegozzen wirt in den lîchamen, sô vergât im diu gestaltnisse und diu varwe, die ez von êrste hâte, und wirt ein einvaltic ding [...] und enpfæhet eine ander geschepfnisse von der sêle und eine ander varwe nâch dem lebene der sêle

[We can take an illustration from what the masters write about nature: when a child is conceived in its mother's womb, it has limbs and colour. But when the soul is infused (gegozzen) into the body, it loses the form and and appearance it first has and becomes something simple [...] and it receives another shape from the soul and another appearance according to the life of the soul]. ${ }^{8}$

The passage causes the scribe of the Oxford manuscript no particular difficulties, and the text continues in its even hand (fol. 66v, fig. 1). The Munich copyist is more troubled, and expects a different image from the one encountered. Instead of 'gegozzen' (=poured), we find 'gezogen' (=pulled or drawn) which is then crossed out and corrected in the margin by the same hand leaving 'gezogen gozzen' (BSB cgm 133, fol. 73r). ${ }^{9}$ The scribe in the Munich manuscript evidently expected a more familiar image: the soul being drawn towards God (continuing the upward movement of the sermon to this point). Instead, he or she found a downward movement, and, even more surprising, the idea of the embodied soul being used as a simile to explain the soul's movement toward God. To conceive of divinity embodied in the normal human soul (over and beyond the special case of Christ's incarnation) needed extra cognitive work for the scribe, and couldn't be properly grasped without re-reading and correction.

Comparing manuscripts thus shows us an example of an Eckhartian image in action. The more educated scribe seems to know what to expect, and is not surprised by Eckhart's bold analogy (or: the boldness has been qualified by the way the text has been corrected to conform to current Dominican teaching on the relation of the different faculties to God). The less educated scribe is both surprised and transformed by the encounter: the lesson is

\footnotetext{
${ }^{7}$ David Albert Jones, The Soul of the Embryo: An Enquiry into the Status of the Human Embryo in the Christian Tradition (London: Continuum, 2003), pp. 120-21.

${ }^{8}$ Largier and Quint, I, pp. 640-42; Eckhart, II, pp. 15-16.

${ }^{9}$ For a fuller discussion of this mistake, see Ben Morgan, 'Rhetorical Transformations: The Meaning of Scribal Errors in Munich Manuscript Staatsbibliothek Cgm 133', Jahrbuch der Meister-Eckhart-Gesellschaft 9 (2015), 179-94, here pp. 93-94.
} 
absorbed and the more radical reading incorporated into the text. Two points in particular should be noted from this. The first has already been spelled out by Freimut Löser's contribution to this volume: working with manuscript variants gives us a more concrete sense of the practices and expectations of which the texts were a part. Überlieferungsgeschichte is an invaluable tool for reconstructing the spiritual practices of which these often abstract theoretical and theological texts were a living part. A second point is the role of embodied experience in Eckhart's preaching, and, more widely, in the spiritual literature of the period. The Munich copyist was surprised by the change of direction: the movement heavenwards being replaced by a progress towards embodiment. Nevertheless, this is a very familiar dynamic in Eckhart's teaching: apophasis frequently gives way to day-to-day images that appeal to the quotidian experience of the listeners and readers, returning them to their embodied life even as they imaginatively transcend the realm of the human to be absorbed in the Godhead. It is the same movement as that which, in Sermon 86, leads Eckhart to prefer the worldly activity of Martha to the disengaged contemplation of Mary. ${ }^{10}$ Attending to the variants in the manuscript transmission, and reading the mistakes and misunderstandings carefully, gives us a window onto the way spiritual aspirants from the fourteenth to the sixteenth centuries encountered, miswrote and re-wrote Eckhartian ideas as they grappled with the lived contradictions that inevitability accompany the desire to find forms of transcendence that do not leave behind our shared human embodiment.

Notes on Contributor:

Ben Morgan is Fellow and Tutor in German at Worcester College, Associate Professor of German, and Co-Convenor of the Oxford Comparative Criticism and Translation Programme at the University of Oxford. He is author of On Becoming God: Late Medieval Mysticism and the Modern Western Self (Fordham UP, 2013), and articles on modernist literature, film and philosophy in the German speaking world (Trakl, Kafka and Kierkegaard, Benjamin and Heidegger, Fritz Lang, Leni Riefenstahl, the Frankfurt School). He is also editor with Carolin Duttlinger and Anthony Phelan of Walter Benjamins anthropologisches Denken (Rombach, 2012), and with Sowon Park and Ellen Spolsky of a Special Issue of Poetics Today on "Situated Cognition and the Study of Culture" (2017).

\footnotetext{
${ }^{10}$ Largier and Quint, II, pp. 214-16. "So Martha is the figure of hospitality in its most elemental form, as hospitality to the flesh, in all its weakness." John D Caputo, The Insistence of God: A Theology of Perhaps (Indiana University Press, 2013), p. 45.
} 